\title{
PRICKLE4 wt Allele
}

National Cancer Institute

\section{Source}

National Cancer Institute. PRICKLE4 wt Allele. NCI Thesaurus. Code C54402.

Human PRICKLE4 wild-type allele is located in the vicinity of 6p21.31 and is approximately $9 \mathrm{~kb}$ in length. This allele, which encodes prickle-like protein 4, may play a role in the regulation of cellular differentiation. The allele is expressed at elevated levels in some breast cancers. 